\title{
INCIDENCE AND SEASONAL FLUCTUATION OF COMMON RODENT SPECIES BY LIVE TRAP UNDER FIELD CONDITIONS AT GIZA AND BEHEIRA GOVERNORATES Hassn, M. F.*; A. A. Farahat ${ }^{\star}$; E. A. Ewais ${ }^{\star *}$; A. A. R. Al-Gendy ${ }^{\star \star *}$ and M. A. Abdel-Wanees* \\ * Agric. Zoology and Nematology Dept. , Fac. of Agric., Cairo Univ. \\ ** Plant protection Dept. , Faculty of Agric., Cairo University. \\ *** Agric. Zoology and Nematology Dept. , Fac. of Agric., Al- Azhar University.
}

\begin{abstract}
The rodent species trapped from different habitats at Giza and Beheira Governorates were recorded. The black rat, $R$. rattus (Linn.), the Norway rat, $R$. norvegicus (Berk.) and the house mouse, Mus musculus Linn., were found at Giza and Beheira Governorates. The Nile grass rat [ $A$. niloticus (Desm.)] was recorded in fields only found at Giza governorate. The roof rat, Rattus rattus (Linn.) was recorded in houses (147 \&108 individuals), fields (20\&134 individuals) and animal buildings (55\&34 individuals) at Giza and Beheira Governorates respectively. In addition, $R$. norvegicus (Berk.) was recorded in animal buildings 85 individuals at Giza Governorate and houses were 85 \& 10 individuals recoded at Giza and Beheira Governorates respectively. A. niloticus (Desm.) was 14 individuals recorded in fields only at Giza Governorate and Mus musculus Linn., was 3 individuals recorded in fields at Giza Governorate and houses was 2 individuals recoded at Giza and Beheira Governorates. The total numbers mature and immature males individuals of $R$. norvegicus (Berk.) were 77indivduals (45.3\%) and 18 individuals (10.6\%) respectively, while mature and immature females individuals were 69 individuals $(40.6 \%)$ and 6 individuals $(3.5 \%)$ respectively. The total numbers mature and immature males individuals of $R$. rattus frugivorous were 68 individuals (51.1\%) and 2 individuals (1.5\%) respectively, while mature and immature females individuals were 56 individuals (42.1\%) and 7 individuals (5.3\%) respectively at Giza Governorate. In the same time, the total numbers mature and immature males individuals of $R$. rattus frugivorous were 65 individuals (42.8\%) and 13 individuals (8.6\%) respectively, while mature and immature females individuals were 63 individuals $(41.4 \%)$ and 16 individuals (10.5\%) respectively at Beheira Governorate. The total numbers mature and immature males individuals of $R$. rattus rattus were 35 individuals (47.3\%) and 6 individuals $(8.1 \%)$ respectively, while mature and immature females individuals were 30 individuals (40.5\%) and 7 individuals (4.1\%) respectively at Giza Governorate. In the same time, the total numbers mature males and females individuals of $R$. rattus rattus were 50 individuals $(42.1 \%)$ respectively, while immature males and females individuals were 11 individuals $(9.2 \%)$ and 8 individuals $(6.7 \%)$ respectively at Beheira Governorate.
\end{abstract}

\section{INTRODUCTION}

On studying rodents under field conditions, the natural history (habitat use, body size, nesting, diet, home ranges etc...) and population dynamics (survival, abundance, reproductive behaviour, and sex ratio etc...), defined by Kesiakova (1999) and Leung (1999). Allover Africa, the occurrence of rodent outbreaks seems to be related to years with unusual rainfall. The seasonal changes of rats population were studied by Hussien (1991) at Fayoum Governorate and Kansouah et al. (1990) in Dahshour 
locality at Giza Governorate. Rodent species composition differed significantly between habitats, Bekele and Leirs (1996). At Beheira Governorate Rattus rattus (Linn.) and addition Rattus norvegicus (Berk.), as well as Mus musculus Linn., were recorded in buildings while Meriones shawi isis (Thomas) and Gerbillus gerbillus (Olivier) were found in field crops while Acomys cahirinus (Desm.) were recorded in buildings and field crops by Metwally et al. (2009). The aim of the present work is to throw light on the incidence and seasonal fluctuation of common rodent species at Giza and Beheira Governorates .

\section{MATERIALS AND METHODS}

The studies which were conducted under the field conditions into two locations, the first location, (Elmansoureia and Abdel-Samad villages in Embaba district at Giza Governorate), $25 \mathrm{~km}$ far from Northern of Giza pyramids, and occupied about 10000 faddans. The second location, (KhaledIbn-El-Waleed and Zeen villages in Bader district at Beheira Governorate). The first village occupied about 2000 faddans and the second occupied about 5000 faddans and most of agricultural areas in both of them were new reclaimed land $15-30$ years ago.

1- Species abundance: -these studies were conducted during the period from January to December 2005 at houses, fields and animal buildings in both Giza and Beheira Governorates. Fifty live traps with spring doors were used for three consecutive nights. Traps were supplied with tomato, luncheon and taameia and were distributed in the mentioned places in the evening, and recollected next morning. The captured individuals were identified and classified according to Osborn and Helmy (1980).

2-Population, sex and age fluctuations: - Fifty live traps were monthly used for two consecutive nights during the period from January to December 2005. Traps distributed at fields were supplied with tomato while those distributed at houses and animal buildings were supplied with taameia or luncheon (reference). Traps were cleaned before use with hot water and liquid soap, then provided with fresh food materials. They were set-up in the evening at 05.00 P.M. and recollected in the next morning at 07.00 A.M. Species, sex and age distributions were recorded. Mature females were killed by chloroform and dissected to determine if they pregnant or not.

\section{RESULTS AND DISCUSSION}

\section{Population density :-}

1-Species abundance:- The rodent species trapped from different habitats at Giza and Beheira Governorates were classified as the following: Family: Muridae, Subfamily: Murinae, Genera: Rattus Fischer[ R. rattus (Linnaeus) and R. norvegicus (Berkenhout)], Arvicanthis Lesson, A. niloticus (Desm.) and Mus Linnaeus, M. musculus Linnaeus. The black rat, $R$. rattus (Linn.), the Norway rat, $R$. norvegicus (Berk.) and the house mouse, Mus musculus Linn., were found at Giza and Beheira Governorates. The Nile grass rat [ $A$. niloticus (Desm.)] was recorded in fields only found at Giza governorate. The roof rat, Rattus rattus (Linn.) was recorded in houses (147 \&108 individuals), 
fields (20\&134 individuals) and animal buildings (55\&34 individuals) at Giza and Beheira Governorates respectively, Table (1).

Table (1): Survey of rodent species at different habitat at Giza and Beheira Governorates during 2005.

\begin{tabular}{|c|c|c|c|c|c|c|c|c|c|c|}
\hline \multirow[b]{3}{*}{ Scientific name } & \multicolumn{10}{|c|}{ Habitats / Governorates } \\
\hline & \multicolumn{2}{|c|}{ Fields } & \multicolumn{2}{|c|}{$\begin{array}{c}\text { Animal } \\
\text { farms }\end{array}$} & \multicolumn{2}{|c|}{ Houses } & \multicolumn{2}{|c|}{ Total } & \multicolumn{2}{|c|}{ (\%) } \\
\hline & $\frac{\mathbb{N}}{\mathbb{N}}$ & 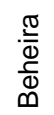 & $\frac{\mathbb{N}}{\mathbb{N}}$ & $\frac{\sqrt[\varpi]{\Phi}}{\frac{\mathscr{L}}{\Phi}}$ & $\frac{\mathbb{N}}{\mathbb{N}}$ & $\begin{array}{l}\frac{\widetilde{L}}{\Phi} \\
\frac{c}{\Phi} \\
\oplus\end{array}$ & $\frac{\mathbb{N}}{\mathbb{N}}$ & $\frac{\sqrt[\varpi]{\Phi}}{\frac{\mathscr{L}}{\Phi}}$ & $\frac{\mathbb{N}}{\mathbb{N}}$ & 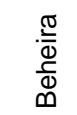 \\
\hline Rattus rattus (Linn.) Total 1,2\&3. & 55 & 34 & 20 & 143 & 147 & 108 & 222 & 285 & 54.01 & 95.32 \\
\hline 1-Rattus rattus rattus & 17 & 15 & 2 & 61 & 55 & 43 & 74 & 119 & 18 & 39.80 \\
\hline 2-Rattus rattus alexandrinus & - & - & 7 & 5 & 8 & 9 & 15 & 14 & 3.65 & 4.68 \\
\hline 3-Rattus rattus frugiforous & 38 & 19 & 11 & 77 & 84 & 56 & 133 & 152 & 32.36 & 50.84 \\
\hline Rattus norvegicus (Berkenhout) & - & - & 85 & - & 85 & 10 & 170 & 10 & 41.36 & 4.01 \\
\hline A. niloticus (Desm.) & 14 & - & - & - & - & - & 14 & - & 3.41 & 0.00 \\
\hline M. musculus Linnaeus & 3 & - & - & - & 2 & 2 & 5 & 2 & 1.22 & 0.67 \\
\hline Total & 72 & 35 & 105 & 144 & 234 & 120 & 411 & 299 & 100 & 100 \\
\hline
\end{tabular}

The color phases of Rattus rattus (Linn.); $R$. rattus frugivorous, $R$. rattus alexandrinus and $R$. rattus rattus were found. The white bellied rat, $R$. rattus frugivorous was recorded in fields(38 \&19 individuals), houses (84\&56 individuals) and animal buildings(11\&77 individuals), while the black bellied rat, $R$. rattus rattus was recorded in fields (17\&15 individuals), houses (55\&43 individuals) and animal buildings (2\&61 individuals), and also the grey bellied rat, $R$. rattus alexandrinus was found in houses (8\&9 individuals) and animal buildings (7\&5 individuals) and not recorded in fields at Giza and Beheira Governorates respectively. In addition, R. norvegicus (Berk.) was recorded in animal buildings 85 individuals at Giza Governorate and houses were 85 \& 10 individuals recoded at Giza and Beheira Governorates respectively. A. niloticus (Desm.) was 14 individuals recorded in fields only at Giza Governorate and Mus musculus Linn., was 3 individuals recorded in fields at Giza Governorate and houses was 2 individuals recoded at Giza and Beheira Governorates. Similar findings consolidate these results were obtained by Kansouah et. al (1990) The population density of the domestic rodents in Dahshour at Giza Governorate. The maximum population of $R$. norvegicus (Berk.) was recorded in houses close to drainage canals while Haraiwi \& Okimasa (2003) mentioned that the rodent population increased following periods when high-quality rice plants were available and vice versa.

\section{2-Population fluctuation:-}

R. norvegicus (Berk.):- Data in Table(2) showed, the seasonal fluctuation of $R$. norvegicus (Berk.) in animal farm and houses at Giza Governorate were 54 individuals $(31.8 \%)$ recorded in Winter as followed Spring, Autumn and Summer,43(25.3\%), 39(22.9\%) and $34(20 \%)$ individuals respectively. The high numbers of $R$. norvegicus (Berk.) were 25 individuals (14.7\%) recorded during February while the lower numbers were 8 individuals $(4.7 \%)$ recorded during March. 
Table (2): Population characteristics of the Norway rat, Rattus norvegicus(Berk.) at Giza Governorate during 2005.

\begin{tabular}{|l|c|c|c|c|c|c|c|c|}
\hline \multirow{3}{*}{ Months } & Dynamic & \multicolumn{7}{|c|}{ Sex and age distributions } \\
\cline { 2 - 9 } & No. & $\%$ & $\begin{array}{c}\text { Mature } \\
\text { J }\end{array}$ & $\begin{array}{c}\text { Immature } \\
\sigma^{*}\end{array}$ & $\begin{array}{c}\text { Total } \\
\text { mature }\end{array}$ & $\begin{array}{c}\text { Pregnant } \\
+\end{array}$ & $\begin{array}{c}\text { Nun } \\
\text { pregnant } \\
+\end{array}$ & $\begin{array}{c}\text { Immature } \\
+\end{array}$ \\
\hline January & 21 & 12.4 & 11 & 0 & 9 & 2 & 7 & 1 \\
\hline February & 25 & 14.7 & 10 & 7 & 7 & 2 & 5 & 1 \\
\hline March & 8 & 4.7 & 5 & 0 & 3 & 1 & 2 & 0 \\
\hline Winter & 54 & 31.8 & 26 & 7 & 19 & 5 & 14 & 2 \\
\hline April & 15 & 8.8 & 5 & 3 & 7 & 4 & 3 & 0 \\
\hline May & 12 & 7.1 & 6 & 2 & 3 & 0 & 3 & 1 \\
\hline June & 16 & 9.4 & 7 & 1 & 7 & 2 & 5 & 1 \\
\hline Spring & 43 & 25.3 & 18 & 6 & 17 & 6 & 11 & 2 \\
\hline July & 9 & 5.3 & 6 & 0 & 3 & 0 & 3 & 0 \\
\hline August & 10 & 5.9 & 5 & 0 & 5 & 3 & 2 & 0 \\
\hline September & 15 & 8.8 & 7 & 1 & 7 & 3 & 4 & 0 \\
\hline Summer & 34 & 20 & 18 & 1 & 15 & 6 & 9 & 0 \\
\hline October & 14 & 8.2 & 6 & 2 & 5 & 0 & 5 & 1 \\
\hline November & 14 & 8.2 & 4 & 2 & 8 & 2 & 6 & 0 \\
\hline December & 11 & 6.5 & 5 & 0 & 5 & 0 & 5 & 1 \\
\hline Autumn & 39 & 22.9 & 15 & 4 & 18 & 2 & 16 & 2 \\
\hline Total & 170 & 100 & 77 & 18 & 69 & 19 & 50 & 6 \\
\hline$\%$ & 100 & - & 45.3 & 10.6 & 40.6 & 11.2 & 29.4 & 3.5 \\
\hline
\end{tabular}

R. rattus frugivorous:- The seasonal fluctuation of $R$. rattus frugivorous in fields at Giza Governorate were 43 individuals (32.3\%) recorded in Spring as followed, Autumn, Summer and Winter ,35,29 and 26 individuals 26.3, 21.8 and $19.5 \%$ respectively. The high numbers of $R$. rattus frugivorous were 18 individuals $(13.5 \%)$ recorded during December while the lower numbers were 4 individuals (3\%) recorded during January. While the seasonal fluctuation of $R$. rattus frugivorous in fields at Beheira Governorate were 40 individuals (26.3\%) recorded in Winter and Spring as followed, Autumn and Summer 39 and 33 individuals 25.7 and $21.7 \%$ respectively. The high numbers of $R$. rattus frugivorous were 16 individuals (10.5\%) recorded during April while the lower numbers were 9 individuals (5.9\%) recorded during September, Table (3).

R. rattus rattus:- The seasonal fluctuation of $R$. rattus rattus in fields at Giza Governorate were 24 individuals $(32.5 \%)$ recorded in Winter as followed, Autumn, Spring and Summer 21,17 and 12 individuals 28.4, 22.9 and 16.2\% respectively. The high numbers of $R$. rattus rattus were 12 individuals $(16.2 \%)$ recorded during March while the lower numbers were 4 individuals $(5.5 \%)$ recorded during June, July, August and September. While the seasonal fluctuation of $R$. rattus rattus in feilds at Beheira Governorate were 35 individuals $(29.4 \%)$ recorded in Autumn as followed, Winter, Spring and Summer 31, 29 and 24 individuals $26.1,24.4$ and $20.2 \%$ respectively. The high numbers of $R$. rattus rattus were 13 individuals (10.9\%) recorded during 
December while the lower numbers were 7 individuals $(5.9 \%)$ recorded during September, Table (4).

3-Age and sex fluctuations:-

$\boldsymbol{R}$. norvegicus (Berk.): The total numbers mature and immature males individuals of $R$. norvegicus (Berk.) were 77indivduals (45.3\%) and 18 individuals $(10.6 \%)$ respectively, while mature and immature females individuals were 69 individuals (40.6\%) and 6 individuals (3.5\%) respectively. The high numbers mature males and females were 26 and 19 individuals recorded during winter respectively, while the lower numbers were 7 and 2 individuals recorded during winter and (winter, spring and autumn) from males and females respectively, Table (2).

R. rattus frugivorous:- The total numbers mature and immature males individuals of $R$. rattus frugivorous were 68 individuals $(51.1 \%)$ and 2 individuals $(1.5 \%)$ respectively, while mature and immature females individuals were 56 individuals $(42.1 \%)$ and 7 individuals (5.3\%) respectively at Giza Governorate. In the same time, the total numbers mature and immature males individuals of $R$. rattus frugivorous were 65 individuals $(42.8 \%)$ and 13 individuals $(8.6 \%)$ respectively, while mature and immature females individuals were 63 individuals (41.4\%) and 16 individuals (10.5\%) respectively at Beheira Governorate. The high seasonally numbers mature males and females were 20 and 18 individuals recorded during Spring respectively, while the lower numbers were 15 and 11 individuals recorded during (winter and summer) and winter from males and females respectively. The high seasonally numbers immature males and females were 4 and 5 individuals recorded during Autumn and Spring respectively, while the lower numbers were 1 individuals recorded during summer and Autumn from females at Giza Governorate. The seasonal fluctuation mature males and females were 18 and 16 individuals recorded during Winter and Autumn followed by Summer and Spring (17 and 12) and 14 individuals respectively at Beheira Governorate. The high numbers mature males and females were 11 and 9 individuals recorded during March and June respectively, while the lower numbers were 2 individuals recorded during (January and February) and January from males and females respectively. The immature males were 2 individuals only during December. The high numbers immature females were 4 individuals recorded during April respectively, while the lower numbers were 1 individuals recorded during June, September and October at Giza Governorate. The high numbers mature males and females were 7 and 9 individuals recorded during March and April respectively, while the lower numbers were 5 and 4 individuals recorded during (February, June, July and December) and January from males and females respectively. The high numbers immature males and females were 3 individuals recorded during April and May respectively. While the lower numbers were 1 individuals recorded during (February, June, July and December) and (January, February, march, July and November) respectively at Beheira Governorate, Table (3).

R. rattus rattus:- The total numbers mature and immature males individuals of $R$. rattus rattus were 35 individuals $(47.3 \%)$ and 6 individuals $(8.1 \%)$ respectively, while mature and immature females individuals were 30 
Hassn, M. F. et al.

individuals $(40.5 \%)$ and 7 individuals $(4.1 \%)$ respectively at Giza Governorate. In the same time, the total numbers mature males and females individuals of $R$. rattus rattus were 50 individuals (42.1\%) respectively, while immature males and females individuals were 11 individuals $(9.2 \%)$ and 8 individuals $(6.7 \%)$ respectively at Beheira Governorate. The high seasonally numbers mature males and females were 12 and 10 individuals recorded during Winter respectively, while the lower numbers were 5 and 4 individuals recorded during summer and winter from males and females respectively at Giza Governorate. The seasonal fluctuation mature males and females were 16 and 14 individuals recorded during Autumn and (Winter and Autumn) followed by (Winter, Summer and Spring 14,12 and 8 individuals) and (Spring and Summer 12 and 10 individuals) respectively at Beheira Governorate. The high numbers mature males and females were 5 and 6 individuals recorded during March respectively, while the lower numbers were 1 individuals recorded during September and (June, July and August) from males and females respectively at Giza Governorate. The high numbers mature males and females were 7 and 6 individuals recorded during December and (January and November) respectively, while the lower numbers were 2 and 3 individuals recorded during April and (June, August and September) from males and females respectively at Beheira Governorate, Table (4). The numbers of rodents are expected to be increased in the appropriate climatic conditions with food availability. Shanker \& Sukumar (1999) stated that, breeding of small mammal populations of mountain forest patches in Southern India was probably influenced by climate and food availability which are seasonal.

\section{4- Pregnancy:-}

The percentage of pregnant females to non-pregnant females' of rodent species trapped at Giza Governorate could be arranged descending according to the number of pregnant females in the following order: Rattus rattus rattus $(8.1 \& 32.4 \%)$ and Rattus rattus frugivorous $(7.5 \& 34.6 \%)$ and Rattus norvegicus (11.2 \&29.4\%), The pregnancy percentage of rodents captured at Beheira Governorate could be arranged descending according to the number of pregnant females in the following order: Rattus rattus rattus (10\&31.9\%) and Rattus rattus frugivorous (10.5\&30.9\%). 
J. Agric. Sci. Mansoura Univ., 34 (7), July, 2009

3

8213 
Hassn, M. F. et al.

4

8214 


\section{REFERENCES}

Harsiwi, T. and Okimasa, M. (2003): Rates of population increase in the rice field rat (Rattus argentiventer) as a function of food supply: An enclosure study in Jatisari, West Java. Journal of Zoology London, 259 (3): 239-244.

Hussien, S. S. M. (1991): Ecological studies and control of certain rodents in Beni-Suef Governorate. M. Sc. Thesis, Faculty of Agriculture, Cairo University, pp.120.

Kansouah, A. S.; El-Zemaity, M. S. and Mikhail, M. W. (1990): Population density of domestic rodents and associates fleas at Dahsour, Giza Governorate. Annual Agricultural Science, Faculty of Agriculture, Ain Shams Univ., 35 (1): $543-550$.

Kesiakova, S, (1999): Studies on the determinating role of the ecological factors for density of sinantropic [sic] rodents in the animal farms and possibilities for control. Veterinarski-Glasnik, 53(1/2): 55-61.

Leung, L. K. P. (1999): Ecology of Australian tropical rainforest mammals, III the Cape York rat, Rattus leucopus (Muridae: Rodentia. WildlifeResearch, 26(3): 317-328.

Metwally, A. M.; Montasser, S.A. and Al-Gendy, A. A. R. (2009): Survey of rodent species and assessment of damage caused by Meriones shawi isis (Thomas) in some field crops at Bustan area. Journal of applied Science Research,(1):42-45.

Osborn, D. and Helmy, I. (1980): The contemporary land mammals of Egypt (including Sinai). Published by Field Museum of National History, London, Fieldiana Zoology, New Series, No. 5: 579.

Shanker, K and Sukumar, R. (1999): Synchrony in small mammal populations of montane forest patches in Southern India. Journal of Animal Ecology, 68(1): 50-59.

Youssef,A. E.S. (1996): Ecological, biological and toxicological studies on rats in stores and shounas .Ph.D. Thesis, Agriculture, Minoufia Univ. pp.132. 
Hassn, M. F. et al.

التواجــ والتغيـرات الموسـمية للقـوارض الثـائعة بواسـطة المصــائد الحيـة تحست الظروف الحقلية فى محافظتى الجيزة والتئية والبحيرة.

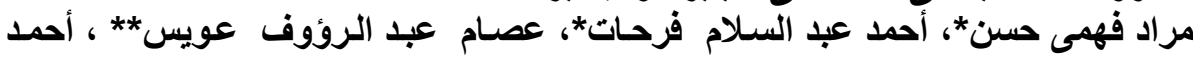

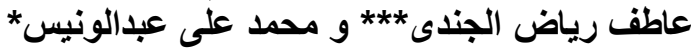

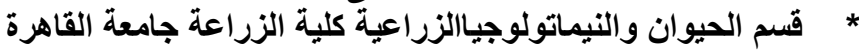

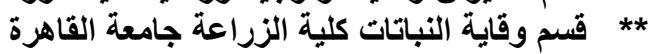

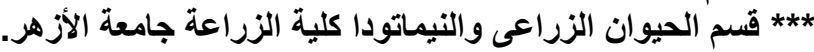

الهدف من البحث حصر و دراسة خواص أعداد القوارض الثائعة بواسطة المصائد الحية

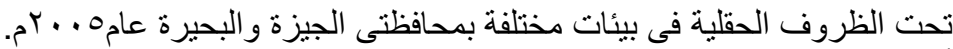
| اوضحت النتائج مايلى :-

تم تسجل الجرذ المتسلق و الجرذ النرويجى وفأر المنزل في محافظتى الجيزة والبحيرة بينما جرذ الحشائش النيلى سجل فى محافظة الجيزة فقط.

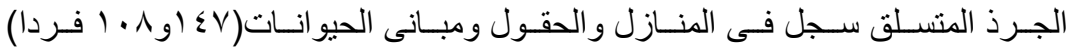

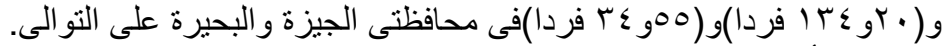

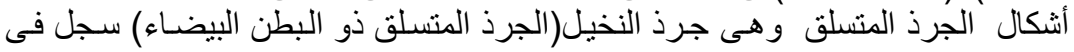

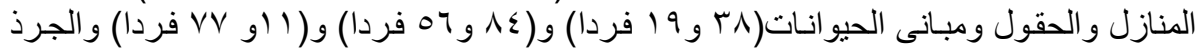

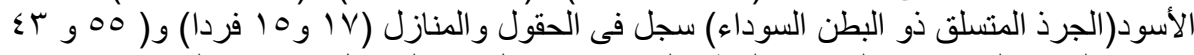

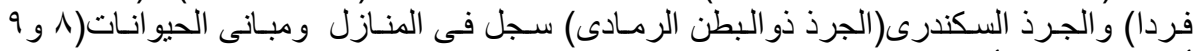

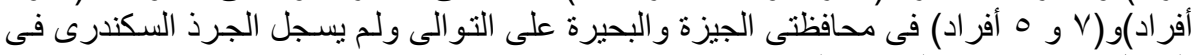

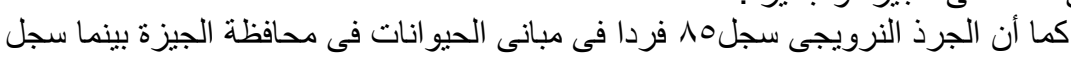

$$
\text { الحقول فى محافظتى الجيزة و البحيرة. }
$$

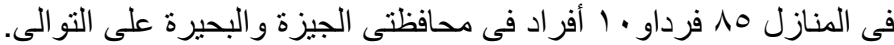

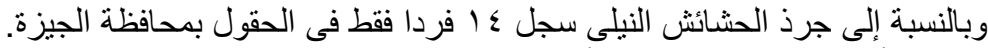

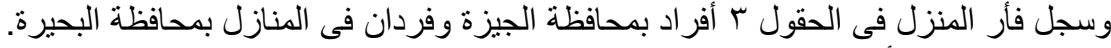

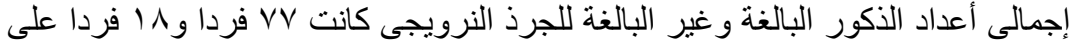

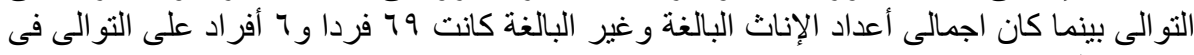

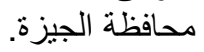

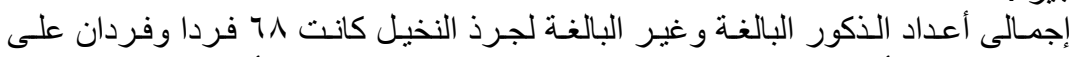

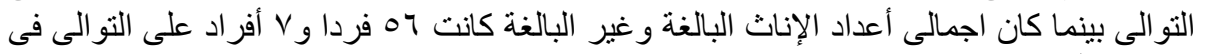

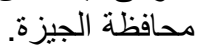

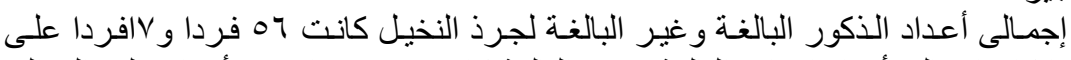

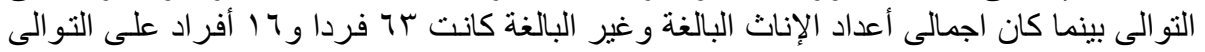

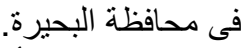

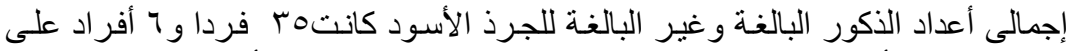

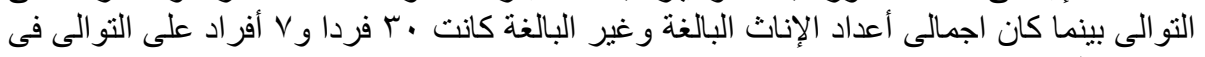

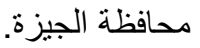

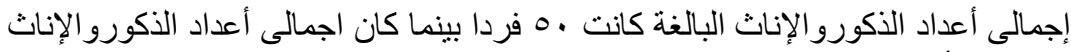
غير البالغة كانت V أفراد و 17 فردا على التوالى النى في محافظة البحيرة. 
J. Agric. Sci. Mansoura Univ., 34 (7), July, 2009 
J. Agric. Sci. Mansoura Univ., 34 (7): 8207 - 8216, 2009 
Table(3): Population characteristics of Rattus rattus rattus at Giza and Beheira Governorates during 2005.

\begin{tabular}{|c|c|c|c|c|c|c|c|c|c|c|c|c|c|c|c|c|}
\hline \multirow[b]{3}{*}{ Months } & \multicolumn{16}{|c|}{ Sex and age distributions } \\
\hline & \multicolumn{2}{|c|}{ Dynamic } & \multicolumn{6}{|c|}{ GizaGovernorate } & \multicolumn{2}{|c|}{ Dynamic } & \multicolumn{6}{|c|}{ Beheira Governorate } \\
\hline & No. & $\%$ & $\underset{\hat{0}}{\text { Mature }}$ & $\underset{\delta}{\text { Immature }}$ & $\begin{array}{c}\text { Total } \\
\text { Mature } \\
\end{array}$ & Pregnant & $\begin{array}{c}\text { Non } \\
\text { pregnant }\end{array}$ & $\begin{array}{c}\text { Immature } \\
q\end{array}$ & No. & $\%$ & $\begin{array}{c}\text { Mature } \\
0\end{array}$ & $\underset{\substack{\lambda \\
\text { Immature }}}{\text { Imm }}$ & $\begin{array}{c}\text { Total } \\
\text { Mature } \\
\end{array}$ & Pregnant & $\begin{array}{c}\text { Non } \\
\text { pregnant }\end{array}$ & $\begin{array}{c}\text { Immature } \\
q\end{array}$ \\
\hline January & 6 & 8 & 4 & 0 & 2 & 0 & 2 & 0 & 12 & 10.1 & 6 & 0 & 6 & 1 & 5 & 0 \\
\hline February & 6 & 8 & 3 & 1 & 2 & 0 & 2 & 0 & 10 & 8.4 & 3 & 2 & 4 & 1 & 3 & 1 \\
\hline March & 12 & 16.2 & 5 & 0 & 6 & 2 & 4 & 1 & 9 & 7.5 & 5 & 0 & 4 & 0 & 4 & 0 \\
\hline Winter & 24 & 32.5 & 12 & 1 & 10 & 2 & 8 & 1 & 31 & 26.1 & 14 & 2 & 14 & 2 & 12 & 1 \\
\hline April & 5 & \begin{tabular}{|l|l|}
6.7 & 1 \\
\end{tabular} & 2 & 1 & 2 & 0 & 2 & 0 & 11 & 9.3 & 2 & 2 & 4 & 2 & 2 & 3 \\
\hline May & 8 & 10.8 & 4 & 0 & 4 & 0 & 4 & 0 & 9 & 7.5 & 3 & 0 & 5 & 2 & 3 & 1 \\
\hline June & 4 & 5.5 & 3 & 0 & 1 & 0 & 1 & 0 & 9 & 7.5 & 3 & 1 & 3 & 0 & 3 & 2 \\
\hline Spring & 17 & 22.9 & 9 & 1 & 7 & 0 & 7 & 0 & 29 & 24.4 & 8 & 3 & 12 & 4 & 8 & 6 \\
\hline July & 4 & 5.5 & 2 & 1 & 1 & 0 & 1 & 0 & 8 & 6.8 & 3 & 1 & 4 & 0 & 4 & 0 \\
\hline August & 4 & 5.5 & 2 & 0 & 1 & 0 & 1 & 1 & 9 & 7.5 & 5 & 1 & 3 & 0 & 3 & 0 \\
\hline September & 4 & 5.5 & 1 & 1 & 2 & 1 & 1 & 0 & 7 & 5.9 & 4 & 0 & 3 & 2 & 1 & 0 \\
\hline Summer & 12 & 16.2 & 5 & 2 & 4 & 1 & 3 & 1 & 24 & 20.2 & 12 & 2 & 10 & 2 & 8 & 0 \\
\hline October & 5 & 6.7 & 3 & 0 & 2 & 0 & 2 & 0 & 11 & 9.3 & 5 & 2 & 4 & 2 & 2 & 0 \\
\hline November & 8 & 10.8 & 3 & 1 & 4 & 2 & 2 & 0 & 11 & 9.3 & 4 & 1 & 6 & 2 & 4 & 0 \\
\hline December & 8 & 10.8 & 3 & 1 & 3 & 1 & 2 & 1 & 13 & 10.9 & 7 & 1 & 4 & 0 & 4 & 1 \\
\hline Autumn & 21 & 28.4 & 9 & 2 & 9 & 3 & 6 & 1 & 35 & 29.4 & 16 & 4 & 14 & 4 & 10 & 1 \\
\hline Total & 74 & 100 & 35 & 6 & 30 & 6 & 24 & 3 & 119 & 100 & 50 & 11 & 50 & 12 & 38 & 8 \\
\hline 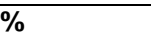 & 100 & - & 47.3 & 8.1 & 40.5 & 8.1 & 32.4 & 4.1 & 100 & - & 42.1 & 9.2 & 42 & 10.1 & 31.9 & 6.7 \\
\hline
\end{tabular}


Table (4): Population Characteristics of Rattus rattus frugivorous at Giza and Beheira Governorates during 2005.

\begin{tabular}{|c|c|c|c|c|c|c|c|c|c|c|c|c|c|c|c|c|}
\hline \multirow[b]{3}{*}{ Months } & \multicolumn{16}{|c|}{ Sex and age distributions } \\
\hline & \multicolumn{2}{|c|}{ Dynamic } & \multicolumn{6}{|c|}{ GizaGovernorate } & \multicolumn{2}{|c|}{ Dynamic } & \multicolumn{6}{|c|}{ Beheira Governorate } \\
\hline & No. & $\%$ & $\begin{array}{c}\text { Mature } \\
\hat{\delta}\end{array}$ & $\underset{\substack{\text { Immature } \\
\delta}}{\ln }$ & $\begin{array}{c}\text { Total } \\
\text { Mature } \\
\text { q }\end{array}$ & Pregnant & $\begin{array}{c}\text { Non } \\
\text { pregnant }\end{array}$ & $\underset{\substack{\text { Immature } \\
+}}{ }$ & No. & $\%$ & $\underset{\delta}{\text { Mature }}$ & $\underset{\delta}{\text { Immature }}$ & $\begin{array}{c}\text { Total } \\
\text { Mature } \\
0\end{array}$ & Pregnant & $\begin{array}{c}\text { Non } \\
\text { pregnant }\end{array}$ & $\underset{\substack{\text { Immature } \\
+}}{ }$ \\
\hline January & 4 & 3 & 2 & 0 & 2 & 0 & 2 & 0 & 14 & 9.2 & 6 & 2 & 5 & 2 & 3 & 1 \\
\hline February & 5 & 3.8 & 2 & 0 & 3 & 1 & 2 & 0 & 13 & 8.6 & 5 & 1 & 6 & 1 & 5 & 1 \\
\hline March & 17 & 12.7 & 11 & 0 & 6 & 1 & 5 & 0 & 13 & 8.6 & 7 & 0 & 5 & 1 & 4 & 1 \\
\hline Winter & 26 & 19.5 & 15 & 0 & 11 & 2 & 9 & 0 & 40 & 26.3 & 18 & 3 & 16 & 4 & 12 & 3 \\
\hline April & 13 & 9.8 & 7 & 0 & 2 & 0 & 2 & 4 & 16 & 10.5 & 4 & 3 & 9 & 2 & 7 & 0 \\
\hline May & 13 & 9.8 & 6 & 0 & 7 & 2 & 5 & 0 & 13 & 8.6 & 4 & 2 & 4 & 1 & 3 & 3 \\
\hline June & 17 & 12.7 & 7 & 0 & 9 & 2 & 7 & 1 & 11 & 7.1 & 4 & 1 & 4 & 1 & 3 & 2 \\
\hline Spring & 43 & 32.3 & 20 & 0 & 18 & 4 & 14 & 5 & 40 & 26.3 & 12 & 6 & 14 & 4 & 10 & 5 \\
\hline July & 9 & \begin{tabular}{|l|}
6.8 \\
\end{tabular} & 5 & 0 & 4 & 0 & 4 & 0 & 14 & 9.2 & 6 & 1 & 6 & 1 & 5 & 1 \\
\hline August & 9 & 6.8 & 4 & 0 & 5 & 0 & 5 & 0 & 10 & 6.6 & 6 & 0 & 4 & 0 & 4 & 0 \\
\hline September & 11 & 8.3 & 6 & 0 & 4 & 0 & 4 & 1 & 9 & 5.9 & 5 & 0 & 4 & 2 & 2 & 0 \\
\hline Summer & 29 & 21.8 & 15 & 0 & 13 & 0 & 13 & 1 & 33 & 21.7 & 17 & 1 & 14 & 3 & 11 & 1 \\
\hline October & 10 & 7.5 & 5 & 0 & 4 & 2 & 2 & 1 & 15 & 9.9 & 6 & 2 & 6 & 2 & 4 & 1 \\
\hline November & 7 & 5.3 & 3 & 0 & 4 & 1 & 3 & 0 & 12 & 7.9 & 6 & 0 & 6 & 2 & 4 & 0 \\
\hline December & 18 & 13.5 & 10 & 2 & 6 & 1 & 5 & 0 & 12 & 7.9 & 6 & 1 & 4 & 1 & 3 & 1 \\
\hline Autumn & 35 & 26.3 & 18 & 2 & 14 & 4 & 10 & 1 & 39 & 25.7 & 18 & 3 & 16 & 5 & 11 & 2 \\
\hline Total & 133 & 100 & 68 & 2 & 56 & 10 & 46 & 7 & 152 & 100 & 65 & 13 & 63 & 16 & 47 & 11 \\
\hline$\%$ & 100 & - & 51.1 & 1.5 & 42.1 & 7.5 & 34.6 & 5.3 & 100 & & 42.8 & 8.6 & 41.4 & 10.5 & 30.9 & 7.2 \\
\hline
\end{tabular}

